\title{
Functional impairment of natural killer cells in active ulcerative colitis: reversion of the defective natural killer activity by interleukin 2
}

\author{
L Manzano, M Alvarez-Mon, L Abreu, J Antonio Vargas, E de la Morena, F Corugedo, A \\ Duràntez
}

\begin{abstract}
We have studied the functional characteristics and clinical importance of the natural killer (NK) cytotoxicity of peripheral blood mononuclear cells (PBMNC) from patients with ulcerative colitis. Normal NK activity was observed in PBMNC from patients with inactive disease, but a pronounced decrease was found in those with active disease. Clinical change from active to inactive disease was associated with enhancement of the depressed NK activity. The impairment of NK cytotoxicity found in patients with active disese could not be ascribed to a deficient number of NK cells as the amounts of $\mathrm{HNK}^{+} \mathrm{I}^{+}, \mathrm{CD16}{ }^{+}$ (Leu 11), and CD11b (OKM1) cells in PBMNC were within normal ranges. This defective cytotoxic PBMNC activity was normalised by short term (18 hour) incubation with recombinant interleukin 2 (rIL-2). Moreover, long term ( 5 day) incubation of these effector cells with rIL-2 induced strong cytotoxic activity against NK resistant and NK sensitive target cells in patients with active and inactive disease. We also found that both precursors and effectors of cytotoxic activity promoted by short term and long term incubation with rIL-2 of PBMNC from the patients showed the phenotype of $\mathrm{NK}$ cells $\left(\mathrm{CD16}^{+}, \mathrm{CD}^{-}\right)$. Taken together, these results show that active ulcerative colitis is associated with a defective function of NK cells that is found to be normal in the inactive stage of the disease. The possible pathogenic and therapeutic implications of these findings are discussed.
\end{abstract}

Medicine I and Service of Gastroenterology, Clinica Puerta de Hierro,

Universidad Autónoma

de Madrid; Service of

Internal Medicine,

Department of Medicine,

Hospital Universitario

Príncipe de Asturias,

Universidad de Alcalá de

Henares, Madrid, Spain

L Manzano

M Alvarez-Mon

L Abreu

J Antonio Vargas

E de la Morena

F Corugedo

A Durántez

Correspondence to:

Professor Melchor Alvarez-

Mon, Departamento de

Medicina, Carretera Madrid-

Barcelona, km 33,600,

Universidad de Alcalá de

Henares, 28871 Alcalá de

Henares, Madrid,

Accepted for publication

7 May 1991 virus infected cells in a major histocompatibility complex (MHC) unrestricted fashion. ${ }^{1-4}$ The NK effectors are large granular lymphocytes that characteristically express the CD16 surface antigen. ' These NK cells have been implicated in immunosurveillance against growth and haematogenous spread of tumours and in resistance to viral and other microbial diseases. ${ }^{1-5}$ The cytotoxic activity of NK cells can be induced or enhanced by certain lymphokines, especially interleukin 2 (IL-2). ${ }^{6-8}$ IL-2 can also generate strong non-MHC restricted cytotoxic activity, referred to as lymphokine activated killer (LAK) cytotoxicity, ${ }^{9-11}$ in peripheral blood mononuclear cells (PBMNC) after longterm (5 day) incubation. There is increasing evidence that the precursors of this LAK cytotoxicity are mainly $\mathrm{CD}^{-}, \mathrm{CD}^{1} 6^{+} \mathrm{NK}$ cells. ${ }^{1213}$

Ulcerative colitis is a chronic systemic inflammatory disease affecting principally the mucosa of the rectum and colon, with a clinical evolution characterised by remissions and exacerbations. The aetiology of this disease remains unknown, but it has been suggested that infectious agents might be involved in the induction of the colonic lesion. ${ }^{1+19} \mathrm{~A}$ possible pathogenic role of the immune system has also been proposed. ${ }^{142021}$

We have investigated the functional characteristics and the clinical importance of the NK activity of PBMNC from patients with ulcerative colitis.

\section{Methods}

\section{PATIENT POPULATION}

Forty eight patients, 28 men and 20 women, mean (SD) age 40 (15) years, with ulcerative colitis diagnosed clinically, radiologically, endoscopically, and pathologically, were studied. Thirty one healthy, age and sex matched subjects were used as control subjects. Disease activity in each patient was analysed according to the criteria of Truelove and Witts. ${ }^{22}$ Twenty four patients, 13 men and 11 women, aged 14-54 years, had active disease (13 mild, 8 moderate, 3 severe). There were 24 patients with inactive disease, 15 men and nine women, aged 23-76 years. When the experimental study was performed 14 patients had been taking steroids plus sulphasalazine for at least three weeks. At the time of the study the remaining 34 patients had not taken steroids for at least three months. Of these, 28 were taking sulphasalazine and six were receiving no specific treatment.
TABLE I Decreased NK cytotoxicity is found in peripheral blood mononuclear cells from patients with ulcerative colitis

\begin{tabular}{llll}
\hline & \multicolumn{3}{l}{ Effector to target ratio } \\
\cline { 2 - 4 } & $50: 1$ & $25: 1$ & $12: 1$ \\
\hline Patients & $28(17)$ & $22(15)$ & $15(13)$ \\
Controls & $48(12)$ & $36(12)$ & $27(11)$ \\
p value & $<0.01$ & $<0.01$ & $<0.01$ \\
\hline
\end{tabular}

Peripheral blood mononuclear cells from 48 patients and 31 control subjects were used as effector cells in cytotoxic assays against ${ }^{\text {s' }} \mathrm{Cr}$-labelled K-562 target cells at the indicated effector to target ratio. The results are expressed as the mean (SD) specific lysis in experiments performed in triplicate in the two groups of subjects. 


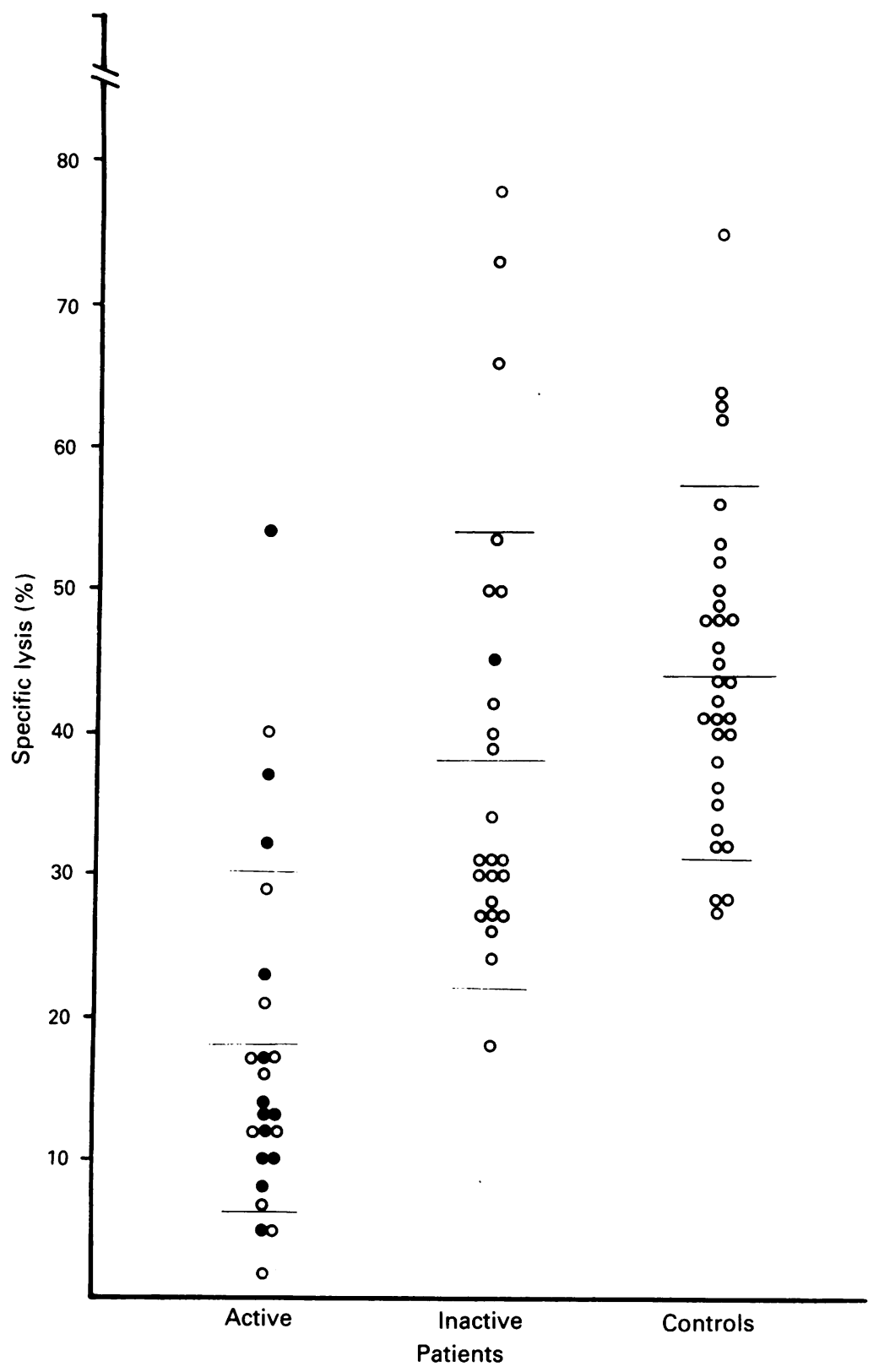

Figure 1: Ulcerative colitis patients with active, but not inactive, disease show impaired NK cytotoxicity in PBMNC. PBMNC from patients with active (24) and inactive (24) disease and from control subjects (31) were used as effector cells against ${ }^{5 l} \mathrm{Cr}$-labelled $K-562$ target cells. Closed circles represent patients taking steroids. Each symbol indicates the mean specific lysis of triplicate cytotoxic assays performed at a 50:1 effector to target ratio for an individual in each group.
ISOLATION OF LYMPHOID CELLS

Peripheral blood mononuclear cells were obtained from the heparinised venous blood of the subjects by Ficoll-Hypaque gradient centrifugation. They were washed twice in phosphate buffered saline $(0 \cdot 15 \mathrm{~mol} / \mathrm{l}, \mathrm{pH} 7 \cdot 2)$, counted, and resuspended in complete medium. Where indicated, PBMNC were treated with anti-CD3 or anti-CD16 monoclonal antibodies plus rabbit complement (Behringwerke AG, Marburg, Germany) as previously described. ${ }^{23}$ These PBMNC lacked surface expression of $\mathrm{CD} 3$ or CD16 antigens $(<1 \%)$, as quantitated by indirect fluorescence and flow cytometry.

\section{CELL CULTURES}

PBMNC $\left(2 \times 10^{6}\right.$ cells $\left./ \mathrm{ml}\right)$ were set up in 24 macrowell plates (Costar, Cambridge, MA) in complete medium supplemented with $10 \%$ fetal calf serum (Gibco, Glasgow, UK), in the presence or absence of different concentrations of IL-2. The cultures were carried out for 18 hours or 5 days at $37^{\circ} \mathrm{C}$ in $5 \% \mathrm{CO}_{2}$ humid atmosphere. The incubated cells were washed twice in complete medium and used as effector cells in the cytotoxicity assays.

\section{CYTOTOXICITY ASSAYS}

Cytotoxicity was quantified by a ${ }^{51} \mathrm{Cr}$-specific release assay using the $\mathrm{K}-562$, JY, Molt-4, P815, and LGL lines as target cells, as previously described..$^{24}$ The different effector cells used were resuspended in complete medium supplemented with $10 \%$ heat inactivated fetal calf serum. Target cells were labelled by incubating 2 to $3 \times 10^{6}$ cells with $150 \mu \mathrm{Ci}$ of ${ }^{51} \mathrm{Cr}$ for 90 minutes at $37^{\circ} \mathrm{C}$, washed twice, and resuspended in complete medium, supplemented with $10 \%$ fetal calf serum, at a concentration of $5 \times 10^{6}$ cells $/ \mathrm{ml}$. Then $5 \times 10^{3}$ target cells $(0.1 \mathrm{ml})$ were mixed with effector cells $(0 \cdot 1 \mathrm{ml})$ at different effector/target ratios $(50 / 1,25 / 1,12 / 1$, and $6 / 1)$ in triplicate roundbottom microwell plates (Linbro, Hamden, CT). Controls included targets incubated either with complete medium supplemented with $10 \%$ fetal calf serum (spontaneous release) or with detergent (total release). Plates were incubated for four hours at $37^{\circ} \mathrm{C}$ in a $5 \% \mathrm{CO}_{2}$ atmosphere; $0.1 \mathrm{ml}$ from each well was collected and counted in a gammacounter. The percentages of specific cytotoxicity were calculated as follows:

$$
\frac{\mathrm{A}-\mathrm{S}}{\mathrm{T}-\mathrm{S}} \times 100
$$

where $A=$ mean cpm of test samples, $S=$ mean $\mathrm{cpm}$ of spontaneous release, and $\mathrm{T}=$ mean $\mathrm{cpm}$ of total release. In all the experiments included, the mean cpm of spontaneous release was always less than $12 \%$ of the mean $\mathrm{cpm}$ of total release.

\section{QUANTITATIVE FLOW CYTOMETRIC STUDY}

Cells were incubated with the specific antibodies, followed by subsequent incubation with a second fluorescein isothiocyanate coupled reagent (Kallestad, Austin, TX), as described elsewhere. ${ }^{25}$ The procedure was performed at $4^{\circ} \mathrm{C}$ in
RPMI 1640 (Gibco, Paisley, UK) supplemented with $1 \%$ L-glutamine (Flow Lab, Irvine, UK), $0.5 \%$ HEPES (Flow Lab), and $1 \%$ penicillinstreptomycin (Difco Lab, Detroit, MI) was used for cultures. This will be referred to as complete medium. 
Figure 2: rIL-2 restores the NK cytotoxicity in $P B M N C$ from patients with active ulcerative colitis. $2 \times 10^{6} \mathrm{PBMNC} / \mathrm{ml}$ from 17 patients - nine active and eight inactive - and 11 control subjects were incubated in the presence of the indicated amounts of rIL-2 for 18 hours. These cultured cells were used as effectors against ${ }^{\prime \prime} \mathrm{Cr}$ labelled $K-562$ target cells. Results represent the mean $(S D)$ of specific lysis in triplicate cytotoxic assays performed at a 50:1 effector to target ratio in the different groups studied.

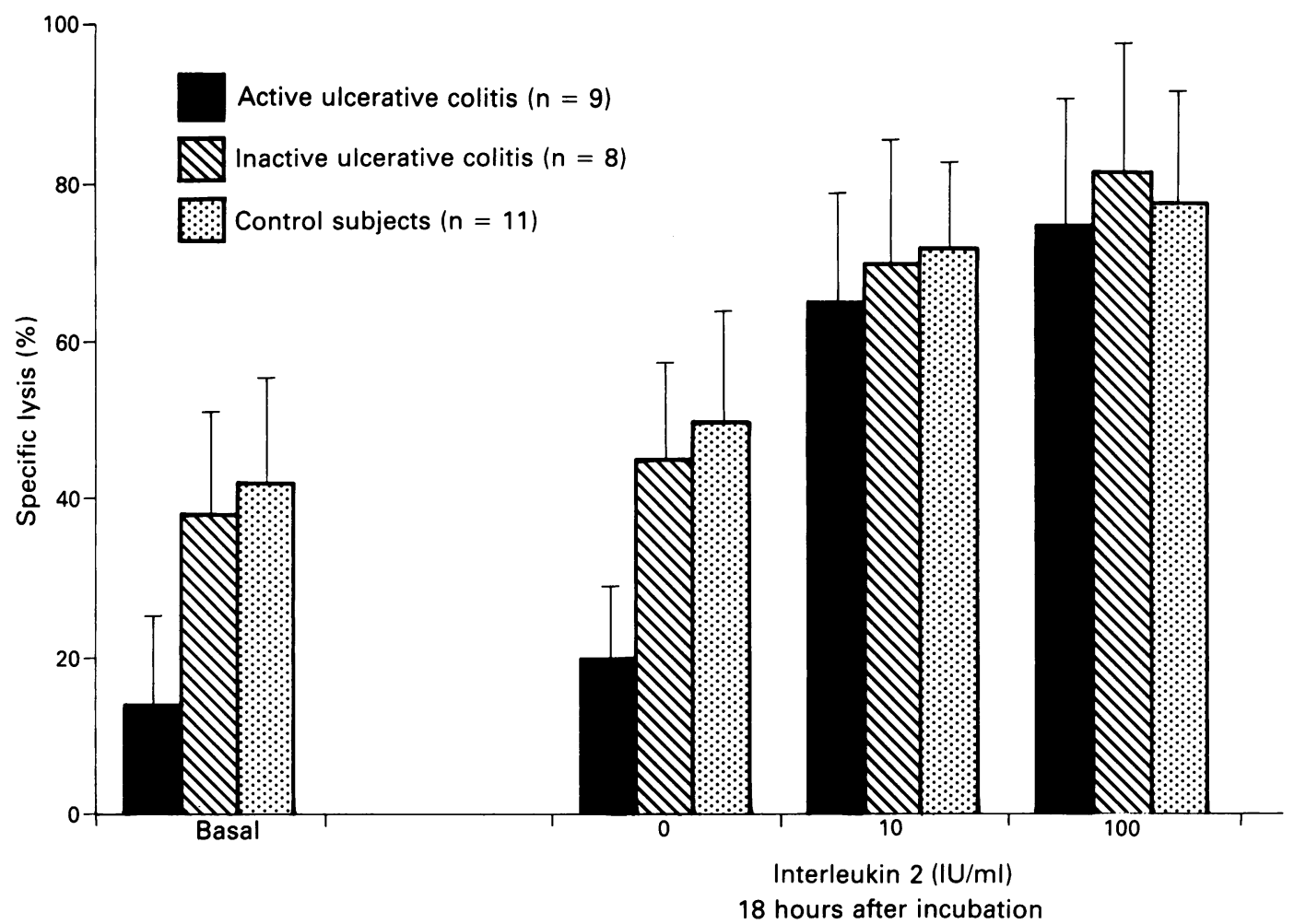

the presence of $0.01 \%$ sodium azide. Surface immunofluorescence was quantified using an EPICS-C flow cytometer (Coulter) equipped with a $2 \mathrm{~W}$ Argon-laser tuned at the 488-nm line.

\section{STATISTICAL METHODS}

The data from the groups were compared using the unpaired Mann-Whitney U test. A $p$ value of less than 0.05 was considered to indicate a significant difference.

\section{Results}

PATIENTS WITH ACTIVE ULCERATIVE COLITIS HAVE QUANTITATIVELY NORMAL BUT FUNCTIONALLY DEFECTIVE NK CELLS IN PBMNC

First, the NK cytotoxic activity of PBMNC from patients with ulcerative colitis was analysed. As Table I illustrates, PBMNC from these patients show a clearly impaired NK cytotoxicity when compared with those of healthy control subjects $(p<0.01)$. Next, we investigated separately the NK activity of PBMNC from ulcerative colitis patients with active and inactive disease. Impairment of cytotoxic activity was evident in patients with active disease, being significantly depressed compared with both patients with inactive disease and healthy control subjects $(\mathrm{p}<0.01)$ (Fig l). However, there were no significant differences in the NK activity of PBMNC from patients with inactive disease when compared with healthy controls $(p>0.05)$. Interestingly, the NK cytotoxicity of PBMNC from patients with active ulcerative colitis who were taking steroids overlapped with that of patients who were not ( $\mathrm{p}>0.05)$.

We also investigated the possible variations in NK activity occurring in PBMNC from ulcer- ative colitis patients who progress from active to inactive disease. The depressed NK activity found in PBMNC from patients with active disease (mean (SD) 11 (4)\% of specific lysis at a 50:1 effector to target cell ratio in six patients) was significantly enhanced $(p<0.01)$ when the disease became inactive $(30(6)) \%$ of specific lysis at a 50:1 effector to target cell ratio). This increase in NK cytotoxicity was also found in one inactive patient who remained on steroid treatment (data not shown).

Quantitative flow cytometry studies were number of phenotypically defined NK cells (Table II). The percentages of $\mathrm{CDI6}^{+}$and HNK $-1^{+}$cells were similar in PBMNC samples from patients with either low or normal NK cytotoxic levels and from healthy control subjects $(p>0.05)$. The numbers of cells bearing CD1lb, a surface heterodimer shared by NK cells and monocytic lineages, were also similar in the three groups of subjects $(p>0.05)$. Consequently, patients with active ulcerative colitis had quantitatively normal but functionally defective NK cells in PBMNC.

\section{IL-2 NORMALISES THE IMPAIRED FUNCTIONAL ACTIVITY OF NK CELLS}

It has been shown that short term incubation with IL-2 can enhance the cytotoxic activity of normal NK cells. Along these lines, we tested the effect of titrated amounts of rIL-2 on the NK cytotoxicity of PBMNC from patients after 18 hours of incubation. In a dose dependent manner, IL-2 enhanced the NK activity of patients with inactive disease and also increased and normalised the defective NK activity of patients with active disease (Fig 2).

It could be argued that the cytotoxicity promoted by rIL-2 against K-562 found in performed simultaneously to ascertain the 
Figure 3: Longterm incubation with rIL-2 induces strong lytic activity in PBMNC from ulcerative colitis patients. $2 \times 10^{6}$ $P B M N C / m l$ from 17 patients - nine active and eight inactive - and 11 control subjects were incubated in the presence of the indicated amounts of rIL-2 for 5 days and used as effectors against ${ }^{5 l} \mathrm{Cr}$ labelled $K-562$. The columns represent the mean (SD) of specific lysis at a 50:1 effector to target ratio in the different groups studied.

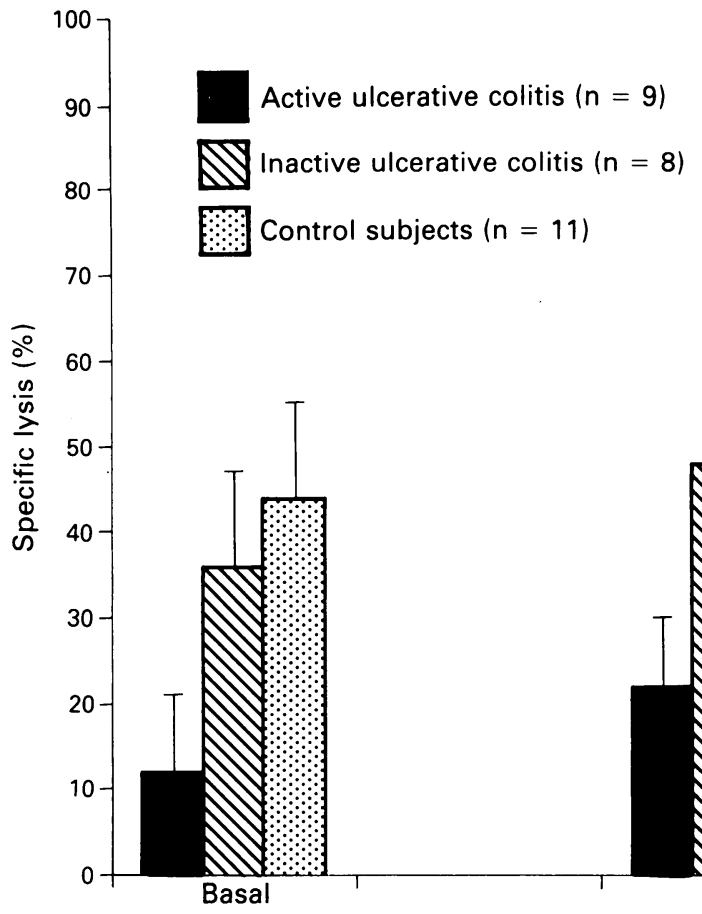

PBMNC from ulcerative colitis patients is mediated by lymphocytes other than NK cells. To investigate whether precursor and effector cells in the IL-2-promoted cytotoxicity belong to NK lineage, PBMNC were selected by means of CD16 or CD3 monoclonal antibodies and complement, and tested by cytotoxic assay. Depletion of $\mathrm{CD} 16^{+} \mathrm{NK}$ cells, but no $\mathrm{CD}^{+} \mathrm{T}$ lymphocytes, abrogated the lytic activity at both precursor and effector levels in PBMNC from patients with active and inactive disease (Table III).

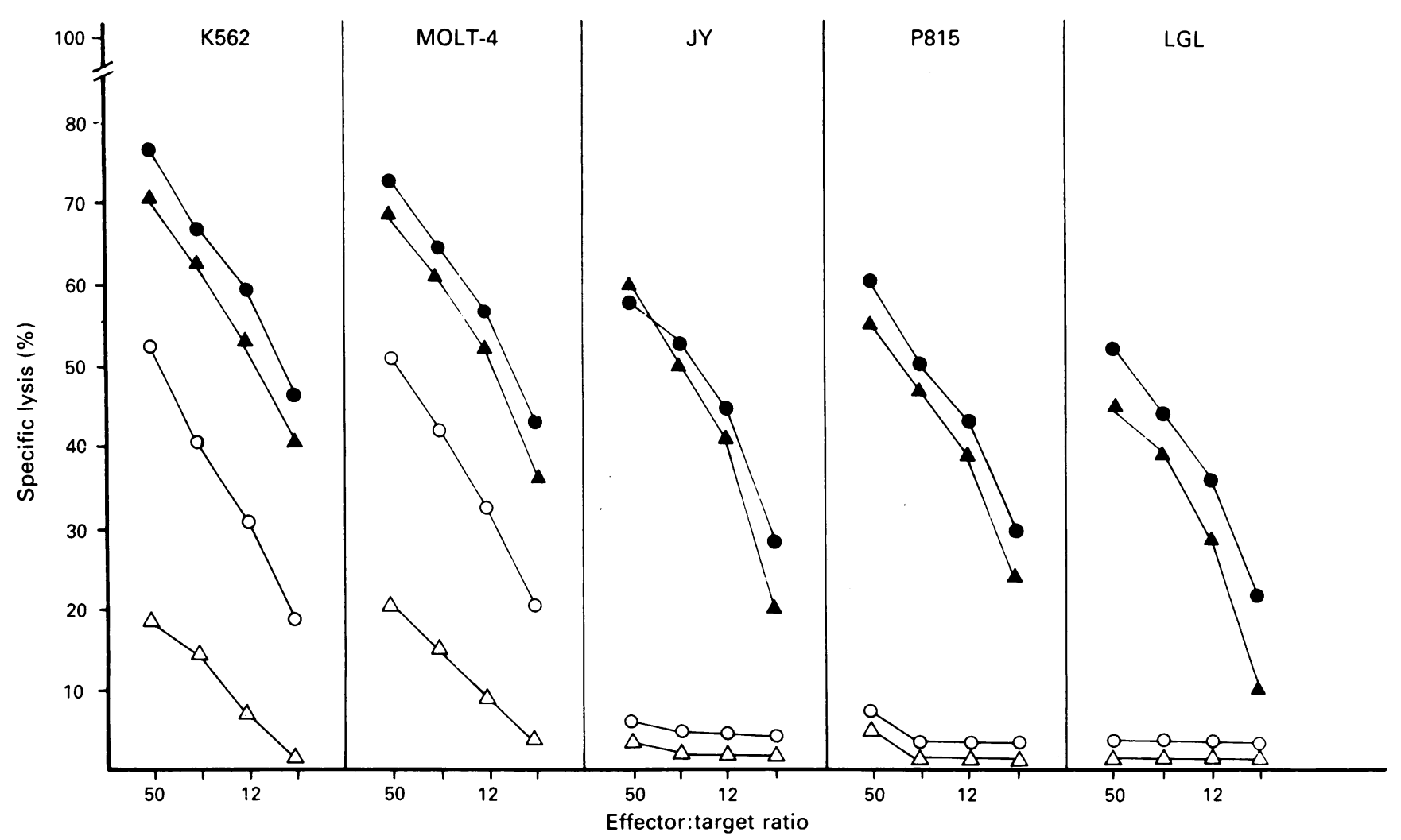

Figure 4: Non-MHC restricted cytotoxicity against both $N K$ sensitive and NK resistant target cells (LAK activity) is promoted in $P B M N C$ from ulcerative colitis patients by longterm incubation with $r I L-2$. In basal conditions (open symbols) or after incubation with 100 IU/ml rIL-2 (closed symbols) for five days, PBMNC from ulcerative colitis patients $(\triangle)$ or control subjects $(\bigcirc)$ were used as effector cells against different " $C r$-labelled NK sensitive and NK resistant target cells. Results represent the mean specific lysis in triplicate cytotoxicity assays performed at a 50:1 effector to target ratio with the different targets studied. A representative experiment of the three performed in patients with active disease is shown. 
TABLE II Impaired NK activity in patients with ulcerative colitis does not correlate with reduced numbers of phenotypically defined NK cells

\begin{tabular}{llll}
\hline & $H N K-1$ & $C D 16$ & $C D 11 b$ \\
\hline Patients & $21(5)$ & $14(3)$ & $34(6)$ \\
Active & $19(5)$ & $12(3)$ & $31(7)$ \\
Inactive & $23(4)$ & $15(4)$ & $37(6)$ \\
Controls & $18(4)$ & $13(5)$ & $36(4)$ \\
\hline
\end{tabular}

Peripheral blood mononuclear cells from 37 ulcerative colitis patients with active (19) or inactive (18) disease and 25 control subjects were studied by indirect immunofluorescence with Leu 7 (HNK 1), Leu 11 (CD16), and OKM1 (CD11b) monoclonal antibodies, and a second step fluoresceinated reagent, as indicated antibodies, and a second step fluoresceinated reagent, as indicated in second step reagent background as quantitated by an EPICS-C flow cytometer. The data are the mean (SD) of each group studied.

TABLE III The precursor and effector lymphocytes of the NK promoted cytotoxicity in peripheral blood mononuclear cells $(P B M N C)$ from patients with ulcerative colitis are $C D 3$, CD16 ${ }^{+}$NK cells

\begin{tabular}{|c|c|c|c|}
\hline & \multicolumn{3}{|c|}{ Patients } \\
\hline & Active & Inactive & $\begin{array}{l}\text { Control } \\
\text { subjects }\end{array}$ \\
\hline $\operatorname{PBMNC}(\mathbf{a})$ & 60 & 68 & 65 \\
\hline $\begin{array}{c}\text { Precursor cells (b) } \\
\text { CD3 }^{-}, \text {CD16 } \\
\text { CD }^{+}, \mathrm{CD}^{+}\end{array}$ & $\begin{array}{l}68 \\
12\end{array}$ & $\begin{array}{l}72 \\
14\end{array}$ & $\begin{array}{l}70 \\
10\end{array}$ \\
\hline Effector cells (c) & & & \\
\hline $\begin{array}{l}\mathrm{CD}^{-}, \mathrm{CD} 16^{\prime} \\
\mathrm{CD}^{+}, \mathrm{CD}^{-}\end{array}$ & $\begin{array}{r}72 \\
8\end{array}$ & $\begin{array}{l}75 \\
10\end{array}$ & $\begin{array}{l}72 \\
12\end{array}$ \\
\hline
\end{tabular}

PBMNC from three patients with active disease and three patients with inactive disease and three control subjects were left patients with inactive disease and three control subjects were left anti-CD16 $\left(\mathrm{CD}^{+}, \mathrm{CD} 16^{-}\right)$monoclonal antibodies plus

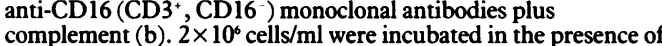
$100 \mathrm{IU} / \mathrm{ml} \mathrm{rIL}-2$ for 18 hours. At the end of the culture period, $100 \mathrm{IU} / \mathrm{ml}$ rIL-2 for 18 hours. At the end of the culture period,
aliquots of untreated PBMNC were treated with anti-CD3 (CD3 $\mathrm{CD}^{+}$) or anti-CD16 $\left(\mathrm{CD}^{+}, \mathrm{CD} \mathrm{16}^{-}\right)$monoclonal antibodies plus complement (c). Cultured cells were used as effectors agains ${ }^{51} \mathrm{Cr}$-labelled K-562 target cells at a 25:1 effector to target ratio. The results are expressed as the mean specific lysis of triplicate experiments performed with the different cellular subpopulations studied in each group of subjects.

TABLE IV $C D 3, C D 16^{+} \mathrm{NK}$ cells are the main precursor and effector lymphocytes of $L A K$ activity

\begin{tabular}{llll}
\hline & \multicolumn{2}{l}{ Patients } & \\
\cline { 2 - 4 } & Active & Inactive & Controls \\
\hline $\begin{array}{l}\text { Peripheral blood } \\
\text { mononuclear cells (a) }\end{array}$ & 45 & 43 & 47 \\
$\begin{array}{c}\text { Precursor cells (b) } \\
\text { CD3 }, \text { CD16 }\end{array}$ & 52 & 55 & 56 \\
CD3 $3^{+}$, CD16 & 4 & 6 & 9 \\
Effector cells (c) & 50 & 48 & 52 \\
CD3, CD16+ & 5 & 4 & 8 \\
CD3 $3^{+}$, CD16 & 5 & & \\
\hline
\end{tabular}

PBMNC from three patients with active disease and three patients with inactive disease and three control subjects were left untreated (a) or were treated with anti-CD3 (CD3 , CD16 $)$ or anti-CD16 (CD3', CD16 ) monoclonal antibodies plus complement (b). $2 \times 10^{6}$ cells $/ \mathrm{ml}$ were incubated in the presence of $100 \mathrm{IU} / \mathrm{ml} \mathrm{rIL}-2$ for 5 days. At the end of the culture period, aliquots of untreated $\mathrm{PBMNC}$ were treated with anti-CD3 $\left(\mathrm{CD}_{3}\right.$ $\mathrm{CD}^{+} 6^{+}$) or anti-CD 16 $\left(\mathrm{CD}^{+}{ }^{+}, \mathrm{CD}^{-} 6^{-}\right)$monoclonal antibodies plus complement (c). Cultured cells were used as effectors agains ${ }_{51} \mathrm{Cr}$-labelled NK resistant JY target cells at a 25:1 effector to target ratio. The results are expressed as the mean specific lysis of triplicate experiments performed with the different cellular subpopulations studied in each group of subjects.

LAK ACTIVITY IS INDUCED IN PBMNC FROM PATIENTS WITH ACTIVE AND INACTIVE DISEASE Longterm incubation with IL-2 can induce nonMHC restricted cytotoxic activity directed against either NK sensitive or NK resistant target cells in PBMNC. ' Thus we investigated the effect of titrated quantities of $\mathrm{rIL}-2$ on the non-MHC restricted lytic cytotoxicity of PBMNC from ulcerative colitis patients after five days of incubation. As shown in Figure 3,
IL-2 induced strong lytic activity against the NK sensitive K-562 target cells in PBMNC from patients with either active or inactive disease. Furthermore, this cytotoxic activity is also directed against different NK sensitive and NK resistant target cells in a non-MHC-restricted fashion (Fig 4).

It has been shown that the lymphocytic precursors and effectors of LAK activity in normal control subjects are mainly $\mathrm{CD}^{+} 6^{+}$, $\mathrm{CD}^{-} \mathrm{NK}$ cells. ${ }^{12}$ We also investigated whether precursor and effector cells of the LAK activity induced in PBMNC from ulcerative colitis patients belong to this lymphocytic subset. We performed a negative selection of PBMNC using CD16 or CD3 monoclonal antibodies plus complement and tested them in the cytotoxicity assay. Both pre- and post-IL-2 incubated PBMNC from ulcerative colitis patients treated with CD16 monoclonal antibody and complement failed to mediate cytotoxic activity. However, the lytic activity of PBMNC was not modified by the initial or final treatment with CD3 monoclonal antibody and complement (Table IV).

\section{Discussion}

In this study we have shown that the levels of NK cytotoxicity in PBMNC from ulcerative colitis patients are related to the clinical activity of the disease. Active disease is associated with the presence in PBMNC of NK cells in normal numbers but functionally defective. However, in patients with inactive disease, these NK cells display normal cytotoxic activity. We also found that the NK cell functional defect found in patients with active disease can be reversed upon in vitro incubation with IL-2.

Previous reports have presented contradictory results concerning the NK activity of PBMNC from ulcerative colitis patients. ${ }^{26-31}$ Our findings of normal NK cytotoxicity in patients with inactive disease but deficient lytic levels in patients with active disease clarify the heterogeneous results in previous series dealing with small numbers of cases which, clinically, were only partially defined.

Our results show that the percentages of NK cells in PBMNC from patients with either active or inactive disease are normal as defined by monoclonal antibodies HNK-1, CD16, and $\mathrm{CD} 1 \mathrm{lb}$, and by quantitative flow cytometry. The simultaneous finding of low levels of NK cytotoxic activity in PBMNC from active patients indicates a diminished lytic efficiency in NK cells from these ulcerative colitis patients. However, we have found in vivo normalisation of the cytotoxicity in patients whose disease progresses from active to inactive. We also show here how short term in vitro incubation of PBMNC with IL-2 from patients with active disease reverses the deficient NK activity. Furthermore, longterm incubation of PBMNC with this lymphokine generates a strong LAK cytotoxicity that is mainly induced and displayed by $\mathrm{CD}_{16}{ }^{+}, \mathrm{CD}^{-}$ NK cells in patients with active and inactive disease. Taken together, these results could suggest that in patients with active disease there is a functional defect in the $\mathrm{NK}$ cell maturation 
from non-cytotoxic precursors to cells that are already cytotoxic and/or in the activation of these lytic effector cells.

NK cells have been involved in the immunosurveillance against neoplasias and infections. ${ }^{12}$ In tumour patients there is increasing evidence that diminution of $\mathrm{NK}$ activity in PBMNC is associated with local progression and dissemination of the disease..$^{32}{ }^{33}$ Defective NK activity in PBMNC has also been associated with a high incidence of severe viral infections. ${ }^{34}$ Low levels of NK activity have been found in PBMNC from patients with chronic viral infections. ${ }^{35}$ However, the pathogenic importance of the NK cell deficiency observed in different inflammatory diseases of unknown aetiology with pronounced disorders of the immune system remains unclear. ${ }^{36}$ Thus our demonstration of the existence of altered NK cells in patients with active ulcerative colitis could be implicated in a predisposition toward the suggested pathogenic action of microbial agents at the intestinal wall. Nevertheless, the functional defect in the NK cells could also be secondary to the pathogenic action of these microbiological agents. Further studies are needed to define the molecular bases and the cause of the functional impairment of NK cells found in patients with active disease. It is feasible to suggest that the defect in NK activity of PBMNC from such patients could be corrected in vivo by treatment with biological immunomodulators such as IL-2, with possible clinical improvement of the disease.

We thank C Lorences, G Peraile, and B Alvarez for their technical help, I Millán for the statistical analysis, and $M$ Messman for her expert editorial assistance. This work was partially supported by grants from the Fondo de Investigaciones Sanitarias de la Seguridad Social, Spain.

1 Ritz J. The role of natural killer cell in immune surveillance. $N$ Eng 7 Med 1989; 320: 1748-9.

2 Janeway CA. Natural killer cells. A primitive immune system. Nature 1989; 341: 108

3 Hercend T, Schmidt RE. Characteristics and uses of natural killer cells. Immunol Today 1988; 9: 291-3.

4 Ortaldo JR, Longo DL. Human natural lymphocyte effector cells: definition, analysis of activity, and clinical effectiveness. F Natl Cancer Inst 1988; 80: 999-1010.

5 García-Peñarrubia P, Koster FT, Kelley RO, McDowell TD, Bankhurst AD. Antibacterial activity of human natural killer cells. $\mathcal{F}$ Exp Med 1989; 169: 99-113.

6 Alvarez de Mon M, Casas J, Laguna R, Toribio ML, O de Landázuri M, Durántez A. Lymphokine induction of NKlike cytotoxicity in T cells from B-CLL. Blood 1986; 67: like cytorox.

7 Trinchieri G, Kobayashi M, Seehra J, London L, Perussia B. Response of resting human peripheral blood natural killer cells to interleukin 2 . $₹$ Exp Med 1984; 160: 1147-69.

8 Sancho L, Martínez-A C, Nogales A, de la Hera A, AlvarezMon $M$. Reconstitution of natural-killer cell activity in the newborn by interleukin-2. $N$ Engl F Med 1986; 314: 57.

9 Grimm EA, Mazumder A, Zhang HZ, Rosemberg SA. Lymphokine-activated killer cell phenomenon. Lysis of natural killer-resistant fresh solid tumor cells by interleukin 2 -activated autologous human peripheral blood lymphocytes. F Exp Med 1982; 155: 1823-41.

10 Bonilla F, Alvarez-Mon M, Merino F, et al. Interleukin-2 induces cytotoxic activity in lymphocytes from regional axillary nodes of breast cancer patients. Cancer 1988; 61: 629-34.

11 Kanof ME, Strober W. Lymphokine-activated killer-cell cytotoxicity in the intestinal immune system. Gastroenterology 1989; $97: 222-4$

12 Herberman RB. Lymphokine-activated killer cell activity. Characteristics of effector cells and their progenitors in blood and spleen. Immunol Today 1987; 8: 178-81.

13 Phillips JH, Lanier LL. Dissection of the lymphokineactivated killer phenomenon. Relative contribution of peripheral blood natural killer cells and $\mathrm{T}$ lymphoctyes to cytolysis. F Exp Med 1986; 164: 814-25.

14 Kirsner JB, Shorter RG. Recent developments in nonspecific inflammatory bowel disease. $N$ Engl f Med 1982; 306: 837 48.

15 Harries AD, Myers B, Cook GC. Inflammatory bowel disease: a common cause of bloody diarrhoea in visitors to the tropics. $B M \mathcal{F}$ 1986; 291: 1686-7.

16 Cave D, Mitchell D, Brooke B. Evidence of an agent transmissible from ulcerative colitis tissue. Lancet 1976; i: 1311-

17 Gitnick GL, Rosen VJ, Arthur MH, Hertweck SA. Evidence for the isolation of a new virus from ulcerative colitis patients. Dig Dis Sci 1979; 24: 609-19.

8 Dickinson RJ, Varian SA, Axon ATR, Cooke EM. Increased incidence of faecal coliforms with in vitro adhesive and invasive properties in patients with ulcerative colitis. Gut 1980; 21: 787-92.

19 Taylor-Robinson S, Miles R, Whitehead A, Dickinson RJ. Salmonella infection and ulcerative colitis. Lancet 1989; i: 1145 .

20 Shorter RG, McGill DB, Bahn RC. Cytotoxicity of mononuclear cells for autologous colonic epithelial cells in colonic nuclear cells for autologous colonic epithel

21 MacDermott RP, Stenson WF. Alterations of the immune system in ulcerative colitis and Crohn's disease. Adv Immunol $1988 ; 42: 285-328$

22 Truelove SC, Witts LJ. Cortisone in ulcerative colitis. Report on therapeutic trial. BMF 1955; 2: 1041-8.

23 Solovera JJ, Alvarez-Mon M, Casas J, Carballido J, Durántez A. Inhibition of human natural killer (NK) activity by calcium channel modulators and a calmodulin antagonist. F Immunol 1987; 139: 876-80.

24 Merino F, Alvarez-Mon M, de la Hera A, Alés JE, Bonilla F, Durántez A. Regulation of natural killer cytotoxicity by 1,25-dihydroxyvitamin $\mathrm{D}_{3}$. Cell Immunol 1989; 118: 32836.

25 Alvarez-Mon M, de la Hera A, Gaspar ML, et al. Proliferation of $B$ cells from chronic lymphocytic leukemia is selectively promoted by B cell growth factor. Acta Haematol 1989; 81: 9l-7.

26 Kemler BJ, Alpert E. Inflammatory bowel disease: study of cell mediated cytotoxicity for isolated human colonic epithelial cells. Gut 1980; 21 : 353-9.

27 Ginsburg CH, Dambrauskas JT, Ault KA, Falchuk ZM. Impaired natural killer cell activity in patients with inflammatory bowel disease: evidence for a qualitative defect. Gastroenterology 1983; 85: 846-51.

28 Fiocchi C, Tubbs RR, Youngman K. Human intestinal mucosal mononuclear cells exhibit lymphokine-activated mucosal mononuclear cells exhibit lymphokine-act

29 Gibson PR, Jewell DP. Local immune mechanisms in inflammatory bowel disease and colorectal carcinoma. Natural matory bowel disease and colorectal carcinoma. Natural
killer cells and their activity. Gastroenterology 1986;90: 12-9.

30 MacDermott RP, Bragdon MJ, Kodner IJ, Bertovich J. Deficient cell-mediated cytotoxicity and hyporesponsiveness to interferon and mitogenic lectin activation by inflammatory bowel disease peripheral blood and intestinal mononuclear cells. Gastroenterology 1986; 90: 6-11.

31 Egawa S, Hiwatashi $\mathrm{N}$. Natural killer cell activity in patients with inflammatory bowel disease. F Clin Lab Immunol 1986; 20: $187-92$.

32 Alvarez-Mon M, Casas J, Laguna R, Jordá J, Durántez A Clinical signification of natural killer activity in B-cell chronic lymphocytic leukemia. Eur $\mathcal{F}$ Haematol 1987; 38: 268-73.

33 Carballido J, Alvarez-Mon M, Solovera J, Menéndez-Ondina $\mathrm{L}$, Durántez A. Clinical significance of natural killer activity in patients with transitional cell carcinoma of the bladder. Urol 1990; 143: 29-33.

34 Biron CA, Byron KS, Sullivan JL. Severe herpesvirus infections in an adolescent without natural killer cells. NEnglf Med 1989; 320: 1731-5.

35 Quinnan GV, Kirmani N, Rook AM, et al. Cytotoxic T cells in cytomegalovirus infection: HLA-restricted T lymphocyte and non-T-lymphocyte cytotoxic responses correlate with recovery from cytomegalovirus infection in bone-marrow transplant recipients. N Engl f Med 1982; 307: 7-13.

36 Gaspar ML, Alvarez-Mon M, Gutiérrez C. Role of interleukin 2 in inducing normalization of natural killer activity in systemic lupus erythematosus. Clin Immunol Immunopathol 1988; 49: 204-14.

37 Hauser SL, Ault KA, Levin MJ, Garovoj MR, Weiner HL. Natural killer cell activity in multiple sclerosis. F Immunol 1981; 127: 1114-7. 